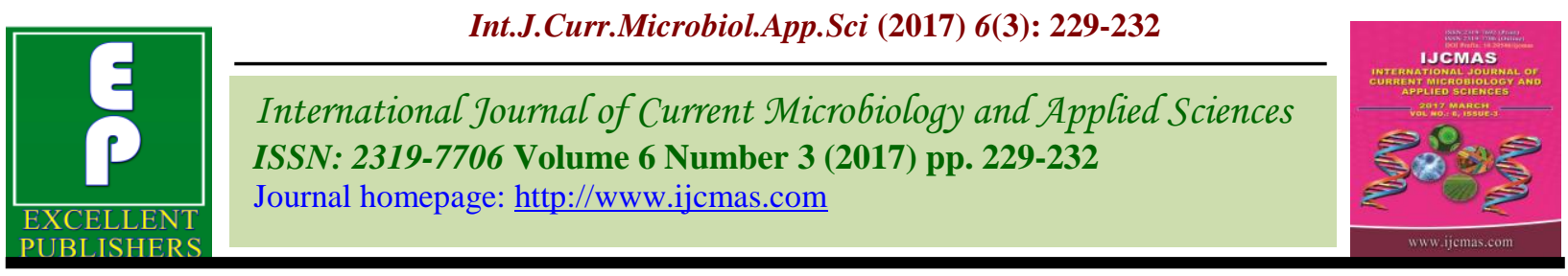

Original Research Article

https://doi.org/10.20546/ijcmas.2017.603.024

\title{
Frequency of Bacterial Pathogens and Antibacterial Susceptibility Pattern of Isolates from Blood Culture - A Retrospective Study from a Tertiary Care Hospital
}

\author{
P. Shankar ${ }^{1 *}$ and M. Kavitha ${ }^{2}$ \\ ${ }^{1}$ Department of Microbiology, Government Villupuram Medical College, Tamilnadu, India \\ ${ }^{2}$ Department of Microbiology, Government Kilpauk Medical College, Tamilnadu, India \\ *Corresponding author
}

A B S T R A C T

\begin{tabular}{|c|c|}
\hline Keywords & $\begin{array}{l}\text { The aim of the present study was to determine the distribution of pathogens and their } \\
\text { antibiotic profile against the commonly used antibiotic therapy. A total of } 5614 \text { blood }\end{array}$ \\
\hline $\begin{array}{l}\text { Blood stream } \\
\text { infection, } \\
\text { Septicemia, } \\
\text { Antibiogram, } \\
\text { Resistance. }\end{array}$ & $\begin{array}{l}\text { specimens from patients were received from intensive care units in Villupuram Medical } \\
\text { College, Tamilnadu, India, were cultured by standard microbiological procedures for the } \\
\text { isolation of pathogens. The isolates were subjected to antimicrobial susceptibility assay to } \\
\text { investigate the resistance pattern of isolates by disc diffusion method and the reports were } \\
\text { analyzed retrospectively over the period of three years from Jan } 2013 \text { to Dec } 2015 \text {. A total }\end{array}$ \\
\hline Article Info & h $951 / 5614(17 \%)$ were found to be positive for blood culture and $4663 / 5614(83 \%)$ \\
\hline $\begin{array}{l}\text { Accepted: } \\
\text { 05 January } 2017 \\
\text { Available Online: } \\
\text { 10 March } 2017\end{array}$ & $\begin{array}{l}\text { positive blood }(\mathrm{n}=951) \text { specimens comprising seven different bacterial pathogens were } \\
\text { reported, of which } 892 / 951(94 \%) \text { were found to be Gram negative bacilli and } 55 / 951(6 \%) \\
\text { were found to be Gram positive cocci. In the present study the antibiogram of Gram } \\
\text { negative bacterial pathogens showed slightly higher resistance rate of all the antibacterials } \\
\text { used in this study. }\end{array}$ \\
\hline
\end{tabular}

\section{Introduction}

The presence of bacteria in the blood circulation is known as Bacteremia, mere presence of bacterial colonization of the blood stream is not usually lethal. Transient bacteremia is due to several physiological conditions without any obvious clinical manifestations (Murty et al., 2007), whereas Septicemia is apparently a medical emergency. The detection of pathogenic growth in a patient's blood has a considerable diagnostic and prognostic importance. Blood cultures provide essential information for the evaluation of a several diseases like endocarditis, pneumonia, pyrexia of unknown origin and particularly, in patients with suspected septicemia (Yagupsky et al., 1990). Bloodstream Infections are a major cause of morbidity and mortality worldwide (Seifer et $a l .$, 2005). The blood culture is a critical tool for the health care professional to detect the pathogenic growth of living organisms in the bloodstream. A positive blood culture can advocate a definitive diagnosis, enable the rite choice of therapy against the specific organisms. The aim of the present study was to determine the distribution of pathogens and 
their antibiotic profile against the commonly used antibiotic therapy.

\section{Materials and Methods}

A total of 5614 blood specimens from patients were received from intensive care units and tested for culture and sensitivity in Villupuram Medical College, Tamilnadu, India, and the reports were analyzed retrospectively over the period of three years from Jan 2013 to Dec 2015.

Blood specimens were cultured according to standard microbiological procedures. The isolates were identified using routine bacteriological procedures by colony morphology, cultural and biochemical methods and subjected to antibacterial assay.

Antibiotic susceptibility testing was carried out by Kirby-Bauer disc diffusion assay on Muller Hinton agar (HiMedia) to determine the antimicrobial susceptibility profiles of pathogenic isolates according to Clinical and Laboratory Standards Institute (CLSI) guidelines (Clinical and Laboratory Standard Institute, 2012). The panel of antibiotic disks (HiMedia) includes aminoglycoside (amikacin 30 $\mu \mathrm{g}$ ), penicillins (ampicillin $10 \mu \mathrm{g}$ ), fluoroquinolones (ciprofloxacin $5 \mu \mathrm{g}$ ). The diameter of the zone of inhibition produced by each antibiotic disk was measured and the result was interpreted as susceptible or resistance to the antibiotics used and the zone of inhibition was compared with the standard chart provided by the manufacturer of the antibiotic disks.

\section{Results and Discussion}

A total of 5614 specimens were collected in a period of three years from Jan 2013 to Dec 2015, of which $951 / 5614(17 \%)$ were found to be positive for blood culture and $4663 / 5614$ (83\%) showed no growth. In the present study 951 isolates were obtained from the culture positive blood $(n=951)$ specimens comprising seven different bacterial pathogens were reported, of which 892/951 (94\%) were found to be Gram negative bacilli and 55/951 (6\%) were found to be Gram positive cocci. Amongst 951 isolates, Klebsiella spp. 499 $(52.5 \%)$ was the predominant bacterial pathogen isolated in our study, followed by 149 (15.7\%) were Pseudomonas spp., 128 (13.5\%) were E. coli, 110 (11.6\%) were Acinetobacter sp., 10 (1\%) were Proteus spp., $44(4.6 \%)$ were Staphylococcus aureus, 11 (1.1\%) were coagulase negative Staphylococcus spp. were reported (Table 1).

Of the 892/951 (94\%) Gram negative bacillus isolated from blood culture was taken for the study by Kirby-Bauer disc diffusion assay against a panel of antibiotics such as amikacin, ampicillin, and ciprofloxacin. Klebsiella SP $(\mathrm{n}=499)$ showed 182/499 (36.5\%), 347/499 (69.5\%), 210/499 (42.1\%) resistance, Pseudomonas sp. $(\mathrm{n}=149)$ showed 70/149 (47\%), 87/149 (58.4\%), 88/149 $(59.1 \%)$ resistance, E. coli $(\mathrm{n}=128)$ showed 43/128(33.6\%), 62/128 (48.4\%),61/128 $(47.7 \%)$ resistance, Acinetobacter $s p .(\mathrm{n}=110)$ showed 42/110 (38.2\%), 71/110 (64.5\%), $58 / 110(53 \%)$ resistance and Proteus sp. $(\mathrm{n}=10)$ showed $3 / 10(30 \%), 5 / 10(50 \%), 4 / 10$ $(40 \%)$ resistance against the panel of antibiotics respectively (Table 2 ).

In the present study we observed the prevalence of Gram negative bacillus was higher than Gram positive bacteria isolated in our study. Our findings are not correlated with a study conducted in Taiwan in 2012, they reported gram positive sepsis was higher than that of gram negative sepsis (Wai et al., 2012). 
Table.1 Distribution of bacterial pathogens isolated from pus

\begin{tabular}{|l|c|}
\hline \multicolumn{1}{|c|}{ Pathogens } & $\begin{array}{c}\text { No. of Isolates } \\
\text { n (\%) }\end{array}$ \\
\hline Klebsiella spp. & $499(52.5 \%)$ \\
\hline Pseudomonas sp. & $149(15.7 \%)$ \\
\hline E. coli & $128(13.5 \%)$ \\
\hline Acenetobacter sp. & $110(11.6 \%)$ \\
\hline Proteus spp. & $10(1 \%)$ \\
\hline Staphlococcus aureus & $44(4.6 \%)$ \\
\hline CoNS & $11(1.1 \%)$ \\
\hline \multicolumn{2}{|c|}{ Total } \\
\hline
\end{tabular}

Table.2 Resistance pattern of Gram negative bacilli isolated from pus

\begin{tabular}{|l|c|c|c|c|c|c|}
\hline & \multicolumn{2}{|c|}{ AK } & \multicolumn{2}{c|}{ AMP } & \multicolumn{2}{c|}{ CIP } \\
\cline { 2 - 7 } & $\mathbf{S}$ & $\mathbf{R}$ & $\mathbf{S}$ & $\mathbf{R}$ & $\mathbf{S}$ & $\mathbf{R}$ \\
\hline \multirow{2}{*}{ Klebsiella sp.(n=499) } & 317 & 182 & 152 & 347 & 289 & 210 \\
& $(63.5 \%)$ & $(36.5 \%)$ & $(30.5 \%)$ & $(69.5 \%)$ & $(57.9 \%)$ & $(42.1 \%)$ \\
\hline \multirow{2}{*}{ Pseudomonas sp.(n=149) } & 79 & 70 & 62 & 87 & 61 & 88 \\
& $(53 \%)$ & $(47 \%)$ & $(41.6 \%)$ & $(58.4 \%)$ & $(40.9 \%)$ & $(59.1 \%)$ \\
\hline \multirow{2}{*}{ E. coli $(\mathbf{n = 1 2 8 )}$} & 85 & 43 & 66 & 62 & 67 & 61 \\
& $(66.4 \%)$ & $(33.6 \%)$ & $(51.6 \%)$ & $(48.4 \%)$ & $(52.3 \%)$ & $(47.7 \%)$ \\
\hline \multirow{2}{*}{ Acinetobacter sp. (n=110) } & 68 & 42 & 39 & 71 & 52 & 58 \\
& $(61.8 \%)$ & $(38.2 \%)$ & $(35.5 \%)$ & $(64.5 \%)$ & $(47 \%)$ & $(53 \%)$ \\
\hline Proteus $(\mathbf{n = 1 0})$ & 7 & 3 & 5 & 5 & 6 & 4 \\
& $(70 \%)$ & $(30 \%)$ & $(50 \%)$ & $(50 \%)$ & $(60 \%)$ & $(40 \%)$ \\
\hline
\end{tabular}

$\mathrm{AK}=$ amikacin, $\mathrm{AMP}=$ ampicillin, $\mathrm{CIP}=$ ciprofloxacin

Klebsiella sp. 499/951 (52.5\%) was found to be highest prevalence of all the organisms isolated from blood culture (Table 1). One of the previous studies showed that Staphylococcus aureus was the predominant pathogen isolated from blood cultures, this finding was not similar and not correlated with the previous studies (Shrestha et al., 2013).

The antibiogram of Gram negative bacilli showed slightly higher resistance rate of all the antibacterials used in this study. Klebsiella sp. (69.5\%) and Acinetobacter sp. (64.5\%), produced highest resistance against ampicillin and also Pseudomonas sp. (59.1\%) and Acinetobacter sp. (53\%) showed higher resistance rates against ciprofloxacin (Table 2).

In the present, study Acinetobacter $s p$. showed higher resistance rate against ampicillin and ciprofloxacin. In this study we observed slightly higher rate of sensitivity against amikacin by all the gram negative bacterial pathogens isolated from blood culture (Table 2).

In conclusion, the present study gives an idea of the current state of etiological agents of blood stream infections and their susceptibility pattern in medical college hospital. As a result accurate and rapid identification of antimicrobial resistance are 
necessary for the timely diagnosis and accurate antibacterial therapy against septicemia.

\section{Acknowledgement}

We acknowledge Mrs. S. Vasanthi, Mr. B. Sathyaperumal, Mrs. K. Parameshwari, Mrs. J. Anu and the DMLT students for the compilation of the data from the records.

\section{References}

Clinical and Laboratory Standard Institute. 2012. Performance standards for antimicrobial susceptibility testing (M100-S22).

Murty, D.S. and Gynashwari, M. 2007. Blood culture in paediatric unit, A study of clinical impact. Indian J. Med. Microbiol., 25: 220-224.
Seifer, T.H. and Wisplinghoff, H. 2005. Blood stream infections and endocarditis. In: borriello FP, Murray PR, Funkes (ed) Topley Wilson, Microbiol. Microbial Infection, Vol 1, ed 10:509-526.

Shrestha, R.K., S.K. Rai, L.K. Khanal and P.K. Mandal. 2013. Bacteriological study of neonatal sepsis and antibiotic susceptibility pattern of isolates in Kathmandu, Nepal, Nepal Med. Coll. J., 15(1): 71-73.

Wai Ho Lim, Reyin Lien, Yhu-Chering Huang, Ming-Chou Chiang, Ren-Huei $\mathrm{Fu}$, et al. 2012. Prevalence and Pathogen Distribution of Neonatal Sepsis Among Very-Low-Birth-Weight Infants, Pediatrics and Neonatol., 53: 228-234.

Yagupsky, P., Nolte, F.S. 1990. Quantitative aspects of septicaemia. Clin. Microbiol. Rev., 3: 269-79.

\section{How to cite this article:}

Shankar, P. and Kavitha, M. 2017. Frequency of Bacterial Pathogens and Antibacterial Susceptibility Pattern of Isolates from Blood Culture - A Retrospective Study from a Tertiary Care Hospital. Int.J.Curr.Microbiol.App.Sci. 6(3): 229-232. doi: https://doi.org/10.20546/ijcmas.2017.603.024 